\title{
My Fictitious Friends and I
}

\author{
Lily Nichol, Simon Fraser University
}

My closest and longest standing friendship is with novels. Books were always there for me when I felt like no one else was. I read about people like me, people I wanted to be, new places, and grand adventures. Reading gave me a refuge when the world around me was not where I wanted to be. Novels were my closest ally while navigating my youth.

In about Grade 4 or 5, I recall receiving a phone call from the library that the book I had placed on hold was available for pick up. At that time in my life, I went to the library weekly and placed many books on hold, but this time things were different. When I arrived to pick up my books, I was handed Alanna: The First Adventure by Tamora Pierce, which I had never seen before and definitely did not put on hold. The librarian at the front desk said, "the children's librarian set this aside for you and said you should go talk to her when you come to pick it up."

Why would the children's librarian have put a book aside for me? I had only spoken to her a few times and did not realize she remembered me. The children's librarian explained, when I went to chat with her, that my enthusiasm for the library had left an impression on her. She told me that she thought this was a book I would like because it had such a fierce heroine. I took it home and ripped through it in just a few days, quickly working my way through the whole series and moving onto other books the librarian left for me. Every weekend we would discuss what I had read that week, and she seemed genuinely interested in my thoughts and ideas. I felt so important!

The librarian's picks for me also encouraged me to discover new books on my own. I loved series the most, like Artemis Fowl, Alex Rider, Silverwing, and Airborn. I loved Kenneth Oppel, Eoin Colfer, Anthony Horowitz, Tamora Pierce, and John Marsden. In reflection, I mostly read male authors who wrote male protagonists at this age. This was likely because I found children's novels so gendered and books with female protagonists often so limited in scope. I stayed

ENGL487W - Summer 2021 
away from them, other than Tamora Pierce and her Alanna novels (and the main character, Alanna, does pretend to be a boy so she is able to go on adventures). I devoured these books. All I wanted at this age was to be an independent adventurer someday - like all my favourite protagonists.

Though I did read to myself, my parents also read to me out loud every night before bed. As I began to near teenhood, I found myself getting bored with being read to, because my parents read out loud much more slowly than I read silently to myself. Sometimes, I would read ahead in the books we were reading together because I was impatient, but I think it hurt their feelings. By twelve I couldn't stand it anymore, and I awkwardly broke the news to my parents that I did not want to be read to. With their reluctant blessing I could now read anything I wanted before bed! I was an independent adventurer like all my favourite characters and had more opportunities to explore new genres of books as well.

At the beginning of the summer between Grades 6 and 7 we moved from an urban centre to a smaller and more rural city where I knew no one. My mother took a position teaching at the university there, and, so that she could prepare for her fall term, we moved in early July well before the start of school. That was the longest, hottest, loneliest, and most boring summer of my life. My already large interest in reading grew into something of even more epic proportions to compensate for my isolation. At the same time, puberty was letting me know that I had a burgeoning interest in boys and my only recourse was Young Adult romantic fiction.

For eight straight weeks, you could find my preteen self chasing the shade across our unfurnished patio to avoid the blistering sun, sitting in a tie-dyed bean bag chair I found at a garage sale down the street, and reading like it was my job. Meg Cabot was my gateway to Young Adult romance novels, and I read every book of hers I could find! One of my favourites was The Mediator series where I met Suze and Jesse, the cute ghost who lived in her bedroom. I also loved The Princess Diaries where I met Mia Thermopolis, the awkward teen princess who finds love. I also discovered Sarah Dessen, John Green, and Maureen Johnson as I sought reprieve from the heat by browsing around the air-conditioned bookstore in my small city's even smaller mall.

Not all of these new authors I discovered wrote romances, but what they all had in common was their teen protagonists struggled to find their place in the world. In my new home and city I saw my struggles mirrored in their pages. It 
made me feel less alone to know that the characters in my novels grappled with their self-confidence, their friendships, their loneliness, and even found starting a new school as scary as I did. I didn't make any human friends that summer, but I certainly made a lot of book friends. I still own every single book Meg Cabot wrote prior to 2004. Though I haven't read any of them recently, they still all maintain a prominent spot on my bookshelf. I find comfort in knowing that they're always nearby, and I know if I need them again they are never far away.

To this day, I am so appreciative of the children's librarian who put books on hold for me and to my local library for having such a strong and amazing children's collection. I'm glad that I had so many opportunities to read growing up. Looking back, I know that finding myself in books was one of the healthiest ways I could have gotten through all the uncomfortable transitions of my youth, including puberty and moving. My bookshelf isn't getting filled at the same rate these days, and the time I have to sit around in a beanbag chair and follow the shade is almost nonexistent. I have allowed my love of reading to fade into the background as I focus my attention elsewhere - though it's less of a choice and more of a necessity as study to become a high school English teacher. My hope is that I will be able to share my love of novels with my future students and encourage them to make friends with books.

(C) Lily Nichol, 2021 